\title{
«...Ис коих один кабинет уже и поднесен...» (К истории минералогического кабинета И. Ф. Генкеля - первой коллекции в собрании музея Московского университета)
}

\author{
260-летнему юбилею Московского университета посвящается
}

\begin{abstract}
Аннотачия: С привлечением новых, относительно ранних (1745-1757 г2.) источников рассмотрены остававшиеся неразрешенньми вопросы истории подаренной Московскому университету братьями Прокофием, Григорием и Никитой Демидовъми минералогической коллекиии саксонского химика и минералога Иоганна Фридриха Генкеля, заложившей основу университетского музея. Обсуждается: где первоначально она находилась (уточняется написание названия и местоположение города); кем и когда была приобретена (А. Н. Демидовым, вероятно, в 1742-1743 г2.); сколькими подобными коллекииями владели Демидовы (не менее чем двумя купленнъми, а также собственной коллекиией, их дополнившей); когда и зачем эти собрания «путешествовали» по России (вопрос не получил однозначного разрешения); в каких городах и домах в них в это время находилисъ, при каких обстоятельствах было офичиально оформлено их дарение университету. В данной статье использован хронологический метод анализа и изложения выявленного в ходе исследований документального материала. Автор предлагает обтяснение причины, по которой коллекиия поступила в университет без описания, утверждает, что такое описание существовало, и выявляет его документальные следы. Отмечено знакомство с этой коллекчией М. В. Ломоносова, высказаны предположения о возможности ее использования в ходе его работы над «Российской минералогией». Рассмотрено, что из связанных с Демидовыми минералогических собраний могло иметь отношение к собранию Генкеля, в том числе являться его остатком. Затронут вопрос о связи минералогических коллекиий Генкеля, купленнъх Демидовым и Академией наук.
\end{abstract}

Ключевые слова: минералогические коллекиии, музей Московского университета, благотворительность, И. Ф. Генкель, Демидовы, М. В. Ломоносов, И. И. Шувалов, Фрейберг, Санкт-Петербург, Москва.

Review: By engaging new and relatively early (1745-1757) sources, the article addresses the remaining unresolved questions regarding the history of the Saxon mineralogist and chemist J. F. Henckel's mineralogical collection, donated to the Moscow university by the brothers Prokofi, Grigoriy and Nikita Demidov, and that laid the foundation for the university's museum. The discussion includes: where the collection was originally located (detailing the writing of the name and the location in the city); when and by whom it was acquired (by A. N. Demidov probably in 1742-1743); how many similar collections the Demidows possessed (no fewer than two acquired, as well as their own collection to supplement the others); when and why these collections "travelled" around Russia (this question has not received a firm answer); in which cities and houses during this time they were located; under which circumstances was the official donation to the university formalised. The author presents an explanation for the reason why the collection entered the university without a description, asserting that such a description had in fact existed and reveals its documental traces. The article notes that M. V. Lomonosov was familiar with this collection and puts forward the supposition of its possible use during his work on "Russian mineralogy". As well, the article examines what pieces linked with the Demidov mineralogical collections could have had ties with the Henckel collection, including being its remnants. The author also touches upon the question of the connection between the mineralogical collections of Henckel bought by the Demidous and by the Academy of sciences.

Key words: I. I. Shuvalov, M. V. Lomonosov, Demidovs, J. F. Henckel, philanthropy, Moscow university museum, mineralogical collections, Freiberg, Saint Petersburg, Moscow.

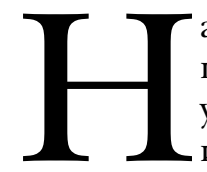

аучная коллекция - одно из важнейших интеллектуальных сокровищ университета классического типа и одновременно один из инстру-

ментов, посредством которых он осуществляет свою деятельность. Значение такие коллекции имеют двоякое - научное и образовательное. Без них затруднено, а в ряде случаев и невозмож- 


\section{Исторический журнал: научные исследования № 1 (25) • 2015}

DOI: 10.7256/2222-1972.2015.1.15676

но развитие некоторых отраслей знания; тем более невозможна передача этих знаний.

Историю отечественных университетских музеев и их коллекций открывает история собрания первого университета России европейского типа - Московского. Начальные страницы любой истории нередко более трудны для восстановления, чем следующие за ними. Особая трудность изучения первых коллекций Московского университета обусловлена тем, что подавляющее большинство составлявших их предметов физически не сохранилось - они погибли в московском пожаре 1812 г. Кропотливые исследования музейных и библиотечных фондов иногда позволяют выделить в них чудом уцелевшие фрагменты ранних собраний. Так, сравнительно недавно были выявлены некоторые избежавшие гибели в огне книги, некогда подаренные университетской библиотеке Демидовыми [4]. Тогда же удалось обнаружить остатки помнившей допожарную Москву пожертвованной ими же естественно-научной коллекции - собрания моллюсков и полипоидов (кораллов). Но последнее не из самых ранних; оно попало в университет в начале XIX в. (В настоящее время демидовская коллекция моллюсков находится в Зоологическом музее МГУ, коллекция кораллов - в Государственном геологическом музее им. В. И. Вернадского $[3,193-195 ; 8,23]$.$) Историю первого собрания$ приходится восстанавливать, увы, исключительно по документам.

Начало коллекциям Московского университета положил поступивший в него в 1759 г. минералогический кабинет, истории которого посвящена эта статья. О факте его дарения было публично оповещено еще в середине XVIII в., но подробности этого и последующих связанных с ним событий стали известны лишь благодаря написанной С. П. Шевыревым юбилейной (1855 г.) «Истории Императорского Московского университета...». Рассказ о кабинете автор поместил в главу, охватывающую кураторство И. И. Шувалова и Л. Блюментроста. Здесь, в параграфе «Частные пожертвования», историк рассказал о благотворительной деятельности наследников Акинфия Никитича Демидова, передавших университету некоторую сумму на содержание студентов, а также «драгоценное собрание» - минералогический кабинет. (Деньги - это 21 тысяча рублей, пожертвованная ими при основании университета $[9,303]$.) Их отец приобрел его в саксонском городе Фрейберге. (Заметим, что в последнее время название этого города пишут по-русски чаще в форме Фрайберг. Учитывая, что нам приходится часто ссылаться на старую литературу, в которой город фигурирует под именем Фрейберг, мы во всех случаях будем употреблять именно эту, с «е» в первом слоге, форму.)

По С. П. Шевыреву, из Фрейберга Демидов вывез кабинет в Петербург, а позже переправил в Сибирь, где, отмечает автор, «Демидов открыл Колыванскую серебряную руду». В Сибири кабинет был «умножен», после чего возращен в Петербург. После смерти владельца его наследники предложили Шувалову «драгоценное собрание безмездно» для Московского университета. В 1759 г. его перевезли в Москву. Здесь оно было «поручено надзору» директора Хераскова и помощника библиотекаря Савича и некоторое время «лежало довольно открыто» в библиотеке. Позднее собрание поступило «в ведение» профессора минералогии Керштенса, а от него в 1770 г. перешло под надзор профессора Афонина. «К сожалению, - замечает С. П. Шевырев, - в актах не осталось ученого описания этому кабинету; но, судя по числовому инвентарю, собрание минералогическое простиралось до 6000 штук» [35, 50-51]. В качестве источника сведений он ссылается на протоколы Университетской конференции.

Из приведенного текста осталось неясным:

- кем собран минералогический кабинет, вывезенный из Фрейберга;

- $\quad$ кто из Демидовых его приобрел;

- $\quad$ в связи с какими обстоятельствами он «путешествовал» по России: сначала был отправлен в Сибирь, оттуда вернулся в Петербург;

- $\quad$ когда состоялось дарение;

- существовало ли первоначальное описание коллекции, и если да, то почему его не осталось в университетском архиве.

Заметим, что отсутствие в тексте С. П. Шевырева ответов на эти вопросы не означает, что историк не сумел извлечь их из источника. Вероятнее, что он их не искал. Перечисленные подробности приобретают значение, если специально интересоваться судьбой кабинета, С. П. Шевырева же волновала история университета в целом. Помещение в готовившемся к юбилею издании частностей, кажущихся сегодня важными, он мог счесть излишне для своего читателя обременительным.

У исследователей, писавших о кабинете позднее, сведения о его истории, как правило, не выходили за пределы сообщенных С. П. Шевыревым. В наиболее авторитетном дореволю- 
ционном своде данных о Демидовых (1888 г.), принадлежащем перу секретаря Демидовского юридического лицея в Ярославле К. Д. Головщикова, пересказан фрагмент текста С. П. Шевырева (при отсутствии прямой на него ссылки) с прибавлением сведений о лицах, в нем упомянутых. Отличий от текста, послужившего оригиналом, у Головщикова мало, и все они могут быть отнесены к неточностям пересказа. (Сказано, например, что коллекция была предложена университету, «куда и доставлена в 1759 году» $[6,52]$. По С. П. Шевыреву, собрание в этом году было перевезено в Москву, а что тогда же было и передано - не говорится.)

$\mathrm{B}$ XX в. корпус сведений о кабинете несколько пополнился. Особенно важна подготовленная Н. А. Пенчко публикация «Документов и материалов по истории Московского университета второй половины XVIII века». Источники, содержащие сведения о кабинете, присутствуют в изданном в 1963 г. последнем, третьем, их томе [10]. Все они относятся к 1770 г.; наиболее интересны протокол Университетской конференции от 13 января, опись коллекции (в том ее составе, который она тогда имела) от 17 марта и два документа, направленные в конференцию, - рапорт профессора М. И. Афонина от 24 марта и письмо профессора доктора И. К. Керштенса от 1 мая.

Публикацию протокола Университетской конференции от 13 января 1770 г. сопроводило объемное примечание. Комментатор в целом следовал схеме, описанной С. П. Шевыревым, но в деталях уточнил ее - отметил, в частности, что дарение кабинета университету было не единовременным актом. Он упомянул об опубликованном в «Санкт-Петербургских ведомостях» за 1755 г. сообщении о том, что Н. А. Демидов «объявил о своем намерении принести в дар новому университету <...> замечательную коллекцию», основой которой послужило «собрание минералов профессора Генкеля» $[10,436]$. Хотя эти слова не вполне точно передали содержание заметки 210-летней давности, они закрепили важную хронологическую веху и указали на происхождение коллекции. Открытием Н. А. Пенчко последнее, впрочем, не являлось. Имя Генкеля эпизодически «всплывало» и после упомянутой публикации в «Ведомостях»- оно не было секретом, в частности, для Г. И. Фишера, подготовившего (1806 г.) описание университетского Музея естественной истории. Но в научном обороте данный факт закрепился благодаря именно Н. А. Пенчко. Ответ на вопрос о составителе ка- бинета после нее уже не пересматривался. Вот имена некоторых воспринявших эту точку зрения исследователей (в скобках -годпубликации): Л. П. Брюшкова (1993), Д. В. Рундквист, Г. Б. Наумов и В. В. Черненко (1998), А. М. Сточик и С. Н. Затравкин (2000), Г. А. Вулисанова (2002), 3. А. Бессуднова (2006).

Установление того факта, что подаренный кабинет - не просто коллекция из Саксонии, но собрание немецкого врача, химика и минералога И. Ф. Генкеля (1678-1744), существенно повышало значимость и объекта, и факта его дарения. Генкель был ученым и преподавателем, получившим международное призвание. Автор первой его биографии X. Грундиг писал (1765 г.), что «его дом был истинной Берг-академией». Знания в ней передавались посредством устных уроков и ознакомления с наглядными пособиями. По его мнению, «даже одно только рассматривание его кабинета и его лаборатории могли многому научить» $[39,152]$. То, что собранная им коллекция позднее покинула Германию (была перевезена в Петербург), минералог А. Брайтхаупт считал большой утратой [39, 97].

На протяжении последующих пятидесяти лет исследование темы продвинулось незначительно. Была исправлена допущенная Н. А. Пенчко неточность в отношении имени покупателя кабинета, названы годы поездки Акинфия за границу. Идея этапности дарения прижилась [32, 135]. При этом авторы выделяют Н. А. Демидова в качестве «первого дарителя». Но многие важные вопросы истории первой коллекции первого музея первого университета России за полтора столетия, прошедших после выхода в свет книги С. П. Шевырева, решены так и не были. Попытаемся ответить хотя бы на некоторые из них, те же, на которые получить ответы пока не удается, - обсудить.

Продвинуться в их решении позволяют обнаруженные нами упоминания о коллекции в материалах, связанных с разделом имущества братьев Демидовых.

После случившейся 18 августа 1745 г. смерти А. Н. Демидова императрица Елизавета Петровна объявила о намерении лично вмешаться в предстоящий раздел его собственности. Указом от 30 сентября она приказала президенту Берг-коллегии А. Ф. Томилову подготовить известие обо всех «имениях» покойного [22, л. 229-230]. (В Полном собрании законов Российской империи этого указа нет.) Распоряжение было исполнено, после чего несколько лет 


\section{Исторический журнал: научные исследования № 1 (25) • 2015}

DOI: $10.7256 / 2222-1972.2015 .1 .15676$

продолжалось согласование вариантов разделения. Произвести окончательное его оформление императрица поручила генерал-адъютанту А. Б. Бутурлину. 1 декабря 1757 г. был оформлен фиксировавший договоренности сторон итоговый документ. Подробности того, как происходила его выработка, раскрывает журнал заседаний, на которые собирались братья. В нем в записи от 26 ноября находим упоминание о минералогическом кабинете: «При том же именованные три брата господа Демидовы представили, что со общаго согласия положили они из отцовъского имения в Московской императорской университет поднесть два выписные минералные кабинета, называемые один Генкелев, а другой Морздорфов, и минеральную ж перемиду, ис коих один кабинет уже и поднесен, и требовали, чтоб оные кабинеты и перемиду ис числа раздела их исключить и о том для ведома записать в журнал, почему и записано» [22, л. 269-269об.].

Запись сообщает новые факты и позволяет объяснить факты уже известные, связав их для реконструкции целостной картины. Один назначенный университету «минеральный» (минералогический) кабинет назван Генкелевым. Нетрудно угадать, на каком основании. Источником сведений для братьев был, несомненно, их отец - его рассказы и, может быть, письма. Таким образом, характеристика коллекции «Санкт-Петербургскими ведомостями» - «собрание $<\ldots>$ вещей $<\ldots>$ славного кабинета господина Генкеля» [16] - полностью подтверждается.

Генкель умер в январе 1744 г., так что Акинфий, если он путешествовал по Саксонии в 1742-1743 гг. (хронология поездки будет обсуждена дальше), вполне мог лично с ним встретиться. Но у него он купил коллекцию или позже у наследников? В жизни Генкеля были моменты, когда он сильно нуждался в деньгах [18, 320], однако материальное его положение в конце жизни нам неизвестно.

Перейдем к обсуждению вопросов, в «постшевыревской» историографии так и не получивших ответа.

Вопрос первый. Кто из Демидовых приобрел кабинет?

Хотя, судя по литературе, после выхода в свет монографии С. П. Шевырева большинством признается, что кабинет купил А. Н. Демидов, существует и другое мнение. В комментарии к документам по ранней истории университета Н. А. Пенчко заявила, что покупателем коллекции был Н. А. Демидов, то есть сын Акинфия.
Можно предложить несколько объяснений тому, как произошла эта замена, и во всех она представляется ошибочной. Первое - расширительное толкование комментатором сообщения в «Санкт-Петербургских ведомостях» (кто дарит тот и купил), второе - простая опечатка (перестановка инициалов местами). В пользу второго говорит то обстоятельство, что Н. А. Пенчко ссылается на работу К. Д. Головщикова, а у него в данном случае речь идет об Акинфии.

Вместе с тем следует учитывать, что начало биографии Никиты Акинфиевича изучено плохо. Утверждать, что в молодые годы он не мог побывать за границей (с отцом или без него), уверенно не приходится.

Обратимся к ранним свидетельствам. В опубликованном переводе письма Керштенса в конференцию от 1 мая 1770 г. фигурирует «первый владелец этого кабинета в России, старый Аким Демидов» $[10,322]$. В немецком оригинале другое: «der alte Akinfi Demidow» [10, 318]. Как видим, Керштенс, видевший коллекцию еще в 1757 г. (т. е. до ее поступления в университет), знал имя прежнего ее владельца - Акинфий.

Письмо Керштенса отразило сведения, полученные им от посторонних лиц. Цитированная выше журнальная запись 1757 г. зафиксировала версию, существовавшую непосредственно в семье Демидовых. Со слов братьев Акинфиевичей журнал сообщает, что коллекция - «из отцовъского имения». Это совпадает с информацией, содержащейся у Керштенса, благодаря чему можно уверенно утверждать, что первым российским владельцем кабинета был А. Н. Демидов.

Историографическая традиция связывает приобретение кабинета с поездкой Акинфия в Саксонию, конкретно во Фрейберг. Упоминаний о ней в литературе немало, но, как правило, они глухие - без дат и фактов. В одной из наших книг мы уже обсуждали вопрос, когда Акинфий мог побывать в Германии. Наиболее подходившим для такой поездки периодом, по нашему мнению, было последнее двадцатилетие его жизни $[36,25]$. Конкретные данные на этот счет приводят А. М. Сточик и С. Н. Затравкин. По их утверждению, Акинфий посетил Фрейберг в 1742-1743 гг. [32, 135], что вполне вписывается в наши построения.

Доказательствами, подтверждающими такую датировку поездки, не располагаем. Но в хронике его местопребывания имеется «окно», удобное для такой поездки. Письма А. Н. Деми- 
дова приказчикам Нижнетагильского завода на период с 20 января по 11 марта 1742 г. [30, л. 1, 5об.] привязывают его к Уралу (в одном, от 3 февраля, прямо сказано, что он - на Невьянском заводе [30, л. 3]). По данным В. И. Байдина, в апреле 1742 г. Акинфий уехал с Урала [23, 53]. Некоторое время он, вероятно, находился в Москве, где происходила коронация императрицы Елизаветы Петровны. Следующее известное нам документальное упоминание о нем относится уже к 1743 г.: 24 марта он оформил свою духовную, при этом своеручно ее подписал [22, л. 302-307]. Где это произошло, в документе не сообщается, но все свидетели (среди них его духовный отец) - жители Тулы, так что локализация события очевидна. Таким образом, поездка Акинфия за границу вполне могла прийтись на период с мая 1742 г. по февраль 1743 г.

Присоединяясь к гипотезе о связи покупки кабинета с поездкой Акинфия в Саксонию, уточним, в каком городе он мог быть приобретен.

В источниках и литературе встречаем два варианта названия интересующего нас города: Фрейберг (С. П. Шевырев, 1855 г; Н. А. Пенчко, 1963 г.), и Фрейбург (И. К. Керштенс, 1770 г.; К. Д. Головщиков, 1881 г.; Г. А. Новицкий, 1963 г.; А. М. Сточик и С. Н. Затравкин, 2000 г.).

Существует несколько городов с похожими названиями. Три Фрейберга: Фрейберг (Freiberg) на реке Фрейбергер-Мульде в Саксонии, Фрейбергна-Неккаре (Freiberg am Neckar) в земле БаденВюртемберг и моравский Фрейберг (Freiberg, ныне город Пршибор) в Чехии. Два Фрейбурга: Фрейбург (Эльбе) (Freiburg (Elbe)) в Нижней Саксонии и Фрейбург-в-Брайсгау (Freiburg im Breisgau) в земле Баден-Вюртемберг.

С горным делом на протяжении столетий был связан саксонский Фрейберг, находящийся в краю горняков и металлургов на реке, стекающей с отрогов Рудных гор. Он был здесь не единственным (другие заметные центры - Мариенберг, Шнееберг [33, 14]), хотя, безусловно, принадлежал к крупнейшим, старейшим и важнейшим горным городам әтого края $[2,178$, 185]. С горным делом был связан и Фрейбург-вБрайсгау. О здешних открытых в XI в. серебряных рудниках по сей день напоминают изображающие рудокопов великолепные витражи городского собора [2, 174].

Сделать окончательный выбор позволяет устойчиво повторяемое в литературе указание на историческую область, в которой располагался город, где был приобретен кабинет. Это неиз- менно Саксония. Ее называет в т. ч. профессор И. К. Керштенс [10, 322], специалист в данной отрасли естественных наук, который, полагаем, не мог перепутать горные области. (А вот описаться в одной букве названия - мог.) Данное обстоятельство подсказывает отдать предпочтение саксонскому Фрейбергу. (То, что в публикации письма Керштенса фигурирует все же не Фрейберг, а Фрейбург, мы склонны считать опиской автора или неточностью текстопередачи при копировании рукописного оригинала.) Правильность выбора подтверждает и тот факт, что именно здесь с 1712 г. жил Генкель [39, 152].

Сказанное, казалось бы, снимает вопрос о происхождении первой минералогической коллекции университета. Возможно, однако, что реальная картина была сложнее. В частности, не исключаем, что в университете под именем Генкелевой хранили коллекцию, включавшую не только Генкелевы и позднее присоединенные к ним сибирские минералы. В выявленных нами документах, относящихся к времени, когда коллекция принадлежала Демидовым, рудных кабинетов упомянуто несколько. В письме вдовы Акинфия 1747 г. (познакомим с ним позже) слово «кабинет» употреблено во множественном лице. В журнале 1757 г. кабинетов также названо два - Генкелев и Морздорфов - и сказано, что братья «положили поднесть» университету оба. Обратим внимание и на письмо Афонина от 24 марта 1770 г., в котором автор, ссылаясь на Керштенса, обсуждает возможность того, что передаваемый ему кабинет «был и двойной», т. е. что коллекция составлена из двух кабинетов $[10,296]$. Афонин не высказывает своего отношения к этому предположению, но нам с учетом свидетельств середины XVIII в. эта гипотеза кажется весьма вероятной. Для ее принятия не хватает одного - данных о том, что Морздорфов кабинет также попал в Московский университет.

В упоминавшемся письме от 1 мая 1770 г. Керштенс, между прочим, упоминает о путешествии коллекции после ее приобретения Демидовым. «...Минеральный кабинет университета, - пишет он, - перевозился с места на место не раз, и даже очень далеко, а именно: из Фрейбурга в Саксонии сперва в Петербург, а оттуда в Сибирь, из Сибири опять в Петербург, а оттуда напоследок в Москву» [10, 322]. Свидетельство это достаточно раннее, фактов, его опровергающих, не имеем.

В связи с ним возникает вопрос второй. По чьей воле, когда и зачем доставленный из Герма- 


\section{Исторический журнал: научные исследования № 1 (25) • 2015}

DOI: 10.7256/2222-1972.2015.1.15676

нии рудный кабинет перемещался по России? Где он, задерживаясь в пути, размещался?

Среди владевших кабинетом Демидовых существовал один, кому он был особенно нужен, его покупатель Акинфий Никитич. Крупнейший уральский горнозаводчик, он хорошо разбирался не только в горнометаллургических технологиях $[34,16-23 ; 37,149,150]$, но также и в полезных ископаемых. Знал признаки минералов и руд, владел приемами их опознания, учил им других. Давал практические советы приказчикам, разбиравшимся в рудах хуже: «Вели побить железом, то он из себя изпустит счетинки чернинькия. Твои, нынешней присылки, как станешь железцом стукать, то кажет он дресву вместо счетинок. Кого ты со оным пошлешь, покажи ему оную пробу, вели ему побить по ребру легонько гвозком или ножевым обухом у обоих камышков, то всяк может разсудить твоеи присылки, что он не магнит» $[34,15]$.

Акинфий руководил разведочными работами, рассылая рудознатцев в перспективные районы. Особое внимание уделял поиску серебряных руд. В отношении них у него и отца была дополнительная мотивация: обнаружить такую руду когда-то обещал Петру Великому основатель промышленной династии; Петр об этом помнил и напоминал. «Лей больше пушкарских снарядов, - писал он Н. Д. Демидову в 1722 г., и отыскивай, по обещанию, серебряную руду» $[6,42]$. Ее искали многие - чтобы убедиться в этом, достаточно посмотреть реестры протоколов Берг-коллегии. (Вот номера некоторых упоминающих ее протоколов за первые годы существования учреждения: 1720 г. [26] - № 45, 166, 407, 497, 609; 1721 г. [27] - № 30, 33, 447, 459, 481, 550.) Но рудоискатели, особенно русские, испытывали острейшую нехватку образцов того, что искали. Открывавшаяся ими якобы серебряная руда чаще всего оказывалась чем-то иным, например колчеданом - «кизом», как в России XVIII в. его по-немецки именовали. (См., например, приговор Берг-коллегии от 13 октября 1721 г. «Об ответствии в Севскую правинцыю о руде, коя в себе содержит кис, а не серебро» $[27$, л. 550].) Посланный в начале 1670 -х гг. с дипломатическим поручением за границу А. А. Виниус среди прочего вез оттуда (из Испании!) образцы руд драгоценных металлов. В статейном списке писал об этом: «...А руд только у одного человека сыскано золотой и серебреной, по куску небольшому тех самых руд, из коих по вся годы из Индей королю серебро и золото привозят; а что за те руды дано - и то писано в росходных тетратех» $[31$, л. 100].

Выдающемуся достижению демидовских металлургов - выделению серебра из алтайских полиметаллических руд - предшествовали долгие годы поисков. Решить задачу удалось лишь в последние годы жизни Акинфия, когда он сумел привлечь на службу высококвалифицированных иностранных специалистов $\Phi$. Трейгера, И. Юнгганса, И. С. Христиани и приобрести рудный кабинет. И специалисты, и минералогическая коллекция прибыли в Россию из Саксонии - исторической области, где серебро добывали по меньшей мере с XII в. [2, 178]. Акинфий Демидов обнаружил алтайское серебро потому, что сумел подготовиться к его открытию в т. ч. своевременно получив в свое распоряжение качественный сравнительный материал. Несомненно, доступ к минералогическим коллекциям мог способствовать успехам его рудознатцев, открывших серебряную руду и вплотную подошедших к открытию золотой.

В отличие от Акинфия его сыновья, из-за затянувшегося раздела наследства надолго отодвинутые от задач развития производства, практической надобности в образцах руд и минералов не испытывали - не считая, конечно, осознания того, что они могли пригодиться им в будущем. И распоряжаться перемещением рудных коллекций после указа от 30 сентября 1745 г., временно лишившего наследников права распоряжения имуществом, возможности они не имели.

Итак, перевезти кабинет в Сибирь могли по распоряжению или А. Н. Демидова (до 18 августа 1745 г.), или кого-то из его семьи (в короткий период между этой датой и 30 сентября того же года). Когда же он туда прибыл? Ответ на этот вопрос важен еще и потому, что способен подсказать, когда и каким образом он пополнялся сибирскими образцами.

Привязать переезды кабинета к календарю возможным пока не представляется, однако некоторые соображения на этот счет высказать можно. Сделать это позволяет еще один новый источник (самый ранний из всех упомянутых прежде) - письмо вдовы Акинфия Демидова Евфимии Ивановны, адресованное московскому приказчику Козме Сергееву 26 августа 1745 г.

(Отметим, что приводимый далее закавыченный текст не является прямой цитатой из этого письма. Это фрагмент его изложения, включенный в написанное более ста лет назад В. Д. Беловым исследование по истории рода 
Демидовых. Однако общее впечатление, оставляемое этим неопубликованным сочинением, не дает повода для сомнений в том, что автором использован подлинный документ и он изложен без существенных искажений.)

В указанном письме Е. И. Демидова помимо прочего приказывает «по присылке из Петербурга от Балакина и из Твери от Сиднева (приказчики А. Н. Демидова. - И. Ю.) горнаго и минеральнаго кабинетов, горной пирамиды и прочих вещей прислать их в Фокино как можно скорее, откуда они будут посланы в Сибирь» [11, л. 162].

Как видим, не только для Акинфия, но и для членов его семьи минералогические собрания обладали весьма высокой ценностью. Всего через неделю после смерти мужа вдова, отдавая срочные распоряжения, не забыла упомянуть и о них.

Приведенный текст дает недостаточно ясное впечатление о положении, в котором они пребывали. Несомненно, однако, что какие-то кабинеты (несколько или один объединенный) находились в это время в России. Если договор о приобретении кабинета Генкеля был заключен во время поездки Акинфия в Саксонию (относимой нами, напомним, к 1742-1743 гг.), то с момента сделки до смерти покупателя времени оставалось приблизительно три года. Его вполне бы хватило, чтобы привезти коллекцию в Петербург еще при жизни А. Н. Демидова. (При отсутствии, разумеется, особых обстоятельств, способных задержать перевозку.)

Из письма также выясняется, что на момент смерти Акинфия (18 августа 1745 г.) кабинеты: a) находились не в Сибири, б) они откуда-то (из Петербурга?) куда-то перевозились с ожидаемой остановкой в Москве. (Эта картина формально вписывается в последовательность переездов, сообщенную в письме Керштенса, если поставить ее в самый конец описанной им цепочки. Но именно формально. У Керштенса слова «наконец в Москву» подразумевают, несомненно, перевозку предметов для передачи в университет.)

Таким образом, пребывание кабинета в Сибири может быть отнесено как к последним годам жизни Акинфия, так и к периоду раздела оставленного им наследства (если туда его отправили еще при его жизни или сразу после смерти, но во исполнение воли покойного). Путешествие коллекции на восток после смерти ее покупателя согласуется с календарем легче, однако не настолько, чтобы можно было решительно предпочесть именно этот вариант.
Выскажем два соображения, которые могут быть полезны при дальнейшей разработке темы.

То, что вдова в августе 1745 г. желает независимо от того, куда везли кабинеты, отправить их на Урал, - вполне объяснимо. Это решение - элемент чрезвычайного плана, к реализации которого она и младший сын приступили немедленно после смерти заводчика. Они намеревались собрать все деньги и ценности в Невьянске, сделав их недоступными для старших сыновей [11, л. 161-162об.]. Не исключаем, кстати, что его (плана) автором мог быть сам умирающий Акинфий.

Также не исключаем, что в 1745 г. коллекции из Петербурга направлялись не в Сибирь, а в старую столицу, вдова же лишь «откорректировала» их маршрут. Предполагаем, в последние годы Акинфий серьезно обдумывал план переноса основного места своего жительства из Невьянска в Москву. Возможно, именно по этой причине на его московских дворах велась в это время масштабная их реконструкция [28, л. 150об.-151]. Готовя здесь резиденцию, сюда же он свозил и кабинеты.

Испытывая затруднение с определением времени пребывания коллекции в Сибири, можно довольно уверенно говорить о месте, в котором она находилась. Маловероятно, чтобы владелец решился держать столь ценное и нужное ему приобретение вдали от своего там дома. Если с Урала на Алтай что и отправлялось, то только образцы руд драгоценных металлов. Основная же часть собрания хранилась, скорее всего, в доме, где жил на Урале А. Н. Демидов в усадьбе на «Старом» (Невьянском) заводе.

Столь же очевидны как вероятные, так и несомненные адреса мест хранения в Петербурге. К концу жизни А. Н. Демидов владел здесь двумя каменными домами. В проекте раздела наследства они описаны так: «дом каменной на погребах о 2 апартаментах со службами на Васильевском острову» и «дом на Фантанке в приходе Симеона Богоприимца каменной на погребах, службы деревянные ветхие, и при нем еще прикупных малых два двора деревянные» [22, л. 249об., 251об.].

Ныне не существующий особняк на Васильевском (снесен при подготовке к строительству Биржи) был построен вскоре после указа об освоении острова - в 1716-1717 гг. [20, 94; 21, $202,203]$. Он находился на берегу Малой Невы недалеко от стрелки (сейчас на этом месте здание Северного пакгауза Васильевского острова набережная Макарова, 2). Первоначально при- 


\section{Исторический журнал: научные исследования № 1 (25) • 2015}

DOI: $10.7256 / 2222-1972.2015 .1 .15676$

надлежал графу Петру Матвеевичу Апраксину. К Демидову владение перешло в 1726 г. [7, л. 1]; по разделу его имущества дом достался Н. А. Демидову.

Здание было обширным и весьма представительным. Место для кабинета как в распакованном виде (в комнатах), так и в запакованном (в подвалах) в нем, несомненно, нашлось бы. Но коллекция могла находиться тут не дольше конца 1747 г. В начале следующего года по указу императрицы в этот дом были перемещены академическая библиотека и Кунсткамера, оставшиеся без крова после пожара, случившегося в палатах Академии наук в декабре 1747 г. [36, 155].

Второй дом, находящийся в приходе церкви Симеона и Анны, достался при разделе Г. А. Демидову, от него перешел к дочерям. Нынешний его адрес - набережная р. Фонтанки, 32 (у пересечения с ул. Белинского) $[12,71 ; 14,40]$. Приобретенный Акинфием рудный кабинет в период раздела имущества мог находиться и тут.

Следующий петербургский адрес коллекции - дом куратора университета И. И. Шувалова, где ее видел И. К. Керштенс. Несомненно, речь идет об одном из красивейших зданий столицы - новопостроенном шуваловском домедворце на нынешней Итальянской улице (строение № 25), начатом по проекту С. И. Чевакинского не позже 1749 г. и завершенном к осени 1754 г. [24, 83]. (К. В. Малиновский полагает, что строительство было закончено годом раньше, а до осени следующего года шли отделочные работы $[15,319]$.$) Хозяин устраивал в нем бле-$ стящие балы и маскарады $[24,83]$. Дом стал одним из очагов культурной жизни Петербурга - в нем бывали М. В. Ломоносов, А. П. Сумароков, Я. Штелин, известные живописцы той поры. Ломоносов в одном из писем Шувалову известил того, что еще до завершения работ посетил дом с целью устройства в нем «обещанных оптических вещей» (письмо от 31 мая 1753 г. [17, 185]). Временное экспонирование в этих стенах доставленного из Европы минералогического кабинета прекрасно вписывается в наши представления о том, какими были этот дом и его хозяин.

Прежде чем перейти к третьему вопросу - о времени дарения университету, - уточним, кто именно выступил дарителем.

В литературе сведения на этот счет расходятся. С. П. Шевырев указал на наследников А. Н. Демидова, и данная версия на текущий момент принята большинством. Но у Н. А. Пенчко треть кабинета дарит Н. А. Демидов, а два года спустя «кабинет целиком» отдают университету «его наследники» $[10,436]$. Вариант по меньшей мере странный. У Н. А. Демидова (младшего сына Акинфия) было трое доживших до зрелого возраста детей: сын Николай и дочери Екатерина и Мария. Никто из них к 1757 г. (второй этап дарения) еще не родился $[13,123]$.

Цитированный выше журнал заседаний 1757 г. вносит в вопрос полную ясность. Кабинет дарили братья Прокофий, Григорий и Никита Демидовы «со общаго согласия».

Перейдем к датам. Напомним свидетельство «Санкт-Петербургских ведомостей», оповестивших, что 17 февраля 1755 г. от Никиты Акинфиевича Демидова в Московский университет была подарена «третья доля славнаго кабинета господина Генкеля, которой состоит из наилутчих минералов, многих куриозных вещей, окаменелых коралей и разных раковин» [16]. Далее разъяснено значение события: «...он господин Демидов первой пример оказал». В отношении музея пример был действительно первым - все синхронные пожертвования ему носили денежный характер $[35,51]$.

Полагаем, однако, что до передачи как таковой дело тогда еще не дошло. До завершения раздела ни один из наследников ничего из отцовского имущества дарить права не имел. Февральская акция Н. А. Демидова была «декларацией о намерениях». С реальностью она сблизилась лишь два с половиной года спустя, когда к нему присоединились братья, по взаимному согласию внесшие соответствующую запись в журнал заседаний, на которых обсуждался предстоящий раздел.

Помимо того, что в поступке братьев отразилось умонастроение века Просвещения, укажем на одно обстоятельство, побуждавшее их расстаться с кабинетом. Естественно-научная коллекция - комплекс, с трудом поддающийся делению: разрушение целого обесценивает части. Попытка оставить его неразделенным порождает, однако, трудности: нужно оценивать сохраненное для выплаты компенсации наследникам, согласившимся от коллекции отказаться. Включение кабинета в раздел сулило задержки в затянувшемся деле. Братья решили их избежать.

Когда же состоялось дарение? Ответ на этот вопрос в значительной степени зависит от того, что понимать под этим словом. Декларация Н. А. Демидова прозвучала, напомним, еще в начале 1755 г. Нам, однако, представляется более правильным в качестве памятной даты вы- 


\section{История науки и техники}

DOI: $10.7256 / 2222-1972.2015 .1 .15676$

брать или 26 ноября 1757 г. (день, когда по требованию братьев было письменно зафиксировано, что они «положили поднесть» университету отцовский кабинет), или 1 декабря того же года (день, когда братья получили «оконченной между ими роздел с росписанием по частям» [22, л. 269oб.]). Особенно выделяем ноябрьскую дату. Записью в журнал коллекция была официально выведена из состава наследства, и наследники получали реальное право ее дарить.

Напомним, что в 1757 г. Керштенс видел Генкелеву коллекцию в доме И. И. Шувалова [10, 322]. Она пребывала там в распакованном виде, т. е., похоже, была уже подарена университету. Эту с ней встречу логично отнести к концу года. Впрочем, допускаем, что кабинет был передан куратору университета несколько раныше времени его исключения из списка подлежащего разделу имущества. В записи от 26 ноября упомянуто, что «один кабинет уже и поднесен»- поднесен, таким образом, раньше того, как братья стали его владельцами. Они и руководивший завершением раздела А. Б. Бутурлин могли согласовать такое решение устно.

Заключительный, четвертый, вопрос: почему в университетском архиве отсутствует «ученое описание» коллекции?

Демидовы подарили кабинет без каталога так, во всяком случае, считали в университете в 1770 г. «...Братьями Демидовыми, как известно, никакого при этой коллекции не дано реестра того, что в ней должно быть и отсутствует» $[10$, 260]. То же - в историографии [3, 20].

Тем не менее трудно поверить, что собрание изначально не имело какого-то описания. Без него невозможно представить передачу коллекции и последующую ее транспортировку. Владелец не мог неописанной коллекцией пользоваться, хранитель не имел возможности обеспечить ее сохранность. Описание (как минимум опись), полагаем, существовало, причем, вероятно, хранилось вместе с кабинетом и с ним же, прибыв в Россию, отправилось по ней в путешествие.

От описания остался и документальный след. Е. П. Пирогова, характеризуя по посмертным описям имущества Акинфия (1758 и 1763 гг.) его библиотеку, наряду с другими сочинениями, излагающими «тонкости производства», отмечает в ней рукописное «Описание собранных покойным саксонским Берг-советником Гениелем рудных металлов и минералов» $[25,16]$. Гениель это, несомненно, Генкель. Перед нами или опечатка, или неправильное прочтение оригинала (буква «к», написанная в виде двух вертикальных черточек, могла быть принята за «и»). Мы полагаем, что как раз эта рукопись и была описанием собрания, об отсутствии которого сожалели в университете. (С названием единственной изданной в России в русском переводе работы этого автора [5] название данной рукописи не перекликается. Отмечаем это, чтобы отклонить возможное предположение, что рукопись из библиотеки А. Н. Демидова копировала текст этого изданного перевода.)

После смерти Акинфия пути коллекции и ее описания, по-видимому, разошлись.

В период раздела ни один из наследников кабинетом не пользовался. Заключаем это из того, что коллекцию подарили без описания: такая ситуация могла возникнуть, только если никто из них не знал, где оно находится. Минералы были отправлены в Петербург, далее - в Москву. Описание застряло в подлежащей разделу библиотеке или архиве заводовладельца. Со временем, скорее всего, доставшееся одному из наследников, оно, может быть, даже не было им замечено. Не исключено, что описание сохранилось и будет обнаружено.

Прогноз в отношении поиска остатков самой коллекции не столь оптимистичен. Поскольку «при пожаре Москвы в 1812 году кабинет сгорел» $[10,436]$, надежд на их обнаружение на первый взгляд не имеется. Однако, если говорить не о собрании в целом, а о его частях, то не исключено, что какие-то из них, растворившись в других коллекциях и утратив индивидуальность, сохранились.

Запись в журнале 1757 г. упоминает не только кабинеты, но и некую «минеральную ж перемиду». Не фрагмент ли это одного из кабинетов?

В собрании Нижнетагильского музея-заповедника «Горнозаводский Урал» хранится рудная пирамида, относящаяся к первой половине XVIII в. Она представляет собой изготовленный из медного сплава конус со срезанной вершиной, к которому прикреплены расположенные в четыре ряда обоймы с закрепленными в них образцами руд. Прежде на вершине пирамиды находился вороток с фигуркой человека у спуска в шахту. Другая одетая по западноевропейской моде фигурка (сохранилась) стояла внутри рудника. Надпись на пластинах у основания пирамиды сообщает о том, что в нее вмонтированы образцы руд с сибирских заводов Акинфия Демидова [19, 18-19]. Но это не означает, что сама пирамида (основа, матрица) была изготовлена 


\section{Исторический журнал: научные исследования № 1 (25) • 2015}

DOI: 10.7256/2222-1972.2015.1.15676

в России. Акинфий мог привезти ее из зарубежной поездки пустой (для последующего заполнения), мог - наполненной образцами, в т. ч. Генкелевыми. В последнем случае перед нами предмет, родственный знаменитому собранию. (Хотя и не часть его. Утративший саксонские руды, он сохранился лишь как связанное с ним экспозиционное оборудование.) Напомним, кстати, что о какой-то путешествовавшей по России вместе с кабинетами «горной пирамиде» упомянула вдова Акинфия в письме, посланном через неделю после смерти супруга. Не об этой ли?

Отделение от кабинета, вероятно, и спасло пирамиду. Основная часть Генкелева собрания погибла в пожаре, тогда как пирамида сохранилась, доставшись Н. А. Демидову.

Важное уточнение: была утрачена московская его часть. Существовала и другая - петербургская, впрочем, вероятно, не связанная с Демидовыми. В посвященном академической библиотеке и Кунсткамере сочинении И. Г. Бакмейстера (1776 г.) присутствует любопытное известие. Даем его в новом переводе, несколько отличающемся от сделанного в XVIII в.: «В 1767 [году] наши минеральные редкости значительно пополнились отборной коллекцией, превышающей 2000 экземпляров, которую Академия приобрела у наследников славного горных дел советника Henckel» [38, 177] (за указание на старый перевод благодарим Е. М. Лупанову).

Сомневаться в достоверности этого сообщения не приходится. Событие и известие о нем разделяют всего 9 лет, автор текста принадлежал к информированной о нем среде - служил академическим библиотекарем.

Бакмейстер пишет, что Академия купила коллекцию у наследников Генкеля, так что связь этой покупки с совершенной за четверть века до нее А. Н. Демидовым сомнительна. Скорее всего, имеем дело с разными коллекциями. Об этом косвенно говорит и то, что в Академию поступило довольно большое собрание (по числу образцов достигавшее трети московского), - незамет- но отделить так много от коллекции Демидовых было невозможно.

Вместе с тем, если не ограничивать себя московским собранием, а ставить вопрос шире, в форме «Что стало с минералогическими коллекциями Генкеля, попавшими в Россию?», легко увидеть направление, в котором следует искать остатки второй из них - академической. Возможно, что они сохранились там, где в настоящее время находятся ранние минералогические собрания Академии наук.

В заключение несколько слов о значении дарения, которому посвящена эта статья.

«...Главным итогом первых 15 лет университета было то, что он наконец вышел из начального возраста и начал нормальную деятельность», - писал А. Ю. Андреев [1, 94]. То же можно сказать и в отношении его коллекций. Они еще будут прирастать и сокращаться, но основа собрания была заложена одновременно с основанием университета. И в основе этой основы демидовские дарения, в т. ч. минералогический кабинет Генкеля.

Заметим также, что он - единственная (кроме академической) крупная систематизированная коллекция минералов и руд, которой мог бы воспользоваться М. В. Ломоносов в случае, если бы вплотную занялся одним из последних крупных своих проектов - написанием «Российской минералогии». Ломоносов познакомился с этим собранием еще во Фрейберге в период учебы у Генкеля. Будучи близок к И. И. Шувалову, бывая в его доме, он наверняка видел в нем и перевезенную в Россию коллекцию своего учителя. С момента первого знакомства с ней Ломоносова собрание приросло, причем, что было для ученого особенно важно, пополнилось уральскими и, может быть, алтайскими образцами. Если Ломоносов предполагал работать с этим кабинетом (который тогда было бы уместно называть уже кабинетом Генкеля-Демидова), он неизбежно должен бы был приехать в Москву и побывать в стенах университета, носящего ныне его имя.

\section{Библиография:}

1. Андреев А. Ю. Лекции по истории Московского университета. 1755-1855. М.: Издательство Московского университета, 2001. $240 \mathrm{c}$.

2. Бакс К. Богатства земных недр. М.: Прогресс, 1986. 384 с.

3. Бессуднова 3. А. Геологические исследования в Музее естественной истории Московского университета. 1759-1930. М.: Наука, 2006. 246 с.

4. Вулисанова Г. А. Три ящика демидовских книг (из истории библиотеки П. Г. Демидова) // Альманах Международного Демидовского фонда. Вып. 2. М.: Классика, 2003. С. 77-86.

5. Генкель И. Ф. Руководство к хемическому рудословию. СПб.: Тип. Сухопут. кад. корпуса, 1775. 248 с.

6. Головщиков К. Д. Род дворян Демидовых. Ярославль: Типография Губернского правления, 1881. 105 с. 


\section{История науки и техники}

DOI: $10.7256 / 2222-1972.2015 .1 .15676$

7. Данная А. Н. Демидова на дом на Васильевском острове, купленный у гр. П. М. Апраксина // Российский государственный архив древних актов. Ф. 1267. Оп. 1. Д. 765.

8. Демидова Н. Г. Род Демидовых: прошлое и настоящее // Альманах Международного Демидовского фонда. М., 2001. C. 7-43.

9. Документы и материалы по истории Московского университета второй половины XVIII века / Подг. к печ. Н. А. Пенчко. Т. 1: 1756-1764. М.: Издательство Московского университета, 1960. 416 с.

10. Документы и материалы по истории Московского университета второй половины XVIII века / Подг. к печ. Н. А. Пенчко. Т. 3: 1767-1786. М.: Издательство Московского университета, 1963. 518 с.

10а.История Московского университета (вторая половина XVIII - начало XIX века). Сборник документов. Том 1: 1754-1755 / Отв. ред. Е. Е. Рычаловский. Сост., вступит. статьи и прим. Д. Н. Костышина. М.: Academia, 2006. 472 с.

11. История рода Демидовых // Российский государственный архив древних актов. Ф. 1267. Оп. 13. Д. 22.

12. Краснова Е. И. Демидовский квартал «за Мойкой у Синего Мосту» // Такие разные Демидовы. СПб.: ИПЦ СПГУТД, 2007. C. 67-83.

13. Краснова Е. И. Демидовы. Родословная роспись // Такие разные Демидовы. СПб.: ИПЦ СПгУТД, 2007. С. 120-142.

14. Краснова Е. И. О генеалогии Демидовых. Новые сведения // Такие разные Демидовы. СПб.: ИПЦ СПГУТД, 2007. С. $39-42$.

15. Малиновский К. В. Санкт-Петербург XVIII века. СПб.: Крига, 2008. 576 с.

16. Минувшего февраля 17 дня... // Санкт-Петербургские ведомости. 1755. № 21. 14 марта.

17. Михаил Васильевич Ломоносов. Переписка. 1737-1765. М.: Ломоносов, 2010. 512 с.

18. Морозов А. А. Ломоносов: Путь к зрелости. 1711-1741. М.; Л.: Издательство АН СССР, 1962. 488 с.

19. Музей горнозаводского дела. Нижний Тагил. Екатеринбург: Баско, 1995. 176 с.

20. Николаева М. В. Санкт-Петербург Петра І. История дворовладений: застройка и застройщики. М.: Прогресс-Традиция, 2014. $1000 \mathrm{c}$.

21. Николаева М. В. Частные застройщики петровского времени - дома-дворцы на набережных Большой и Малой Невы // Петровское время в лицах - 2008. СПб., 2008. С. 187-207.

22. Об имениях и заводах наследников Никиты и Акинфия Демидовых. 1702-1786 // Российский государственный архив древних актов. Ф. 11. Оп. 1. Д. 95. Ч. 2.

23. Очерки истории культуры и быта старого Невьянска. Люди, памятники, документы / Под ред. В. И. Байдина. Екатеринбург: Издательство Уральского университета, 2001. $248 \mathrm{c.}$

24. Петров А. Н. Савва Чевакинский. Л.: Лениздат, 1983. 158 с.

25. Пирогова Е. П. Библиотеки Демидовых: книги и судьбы. Екатеринбург: Сократ, 2000. 208 с.

26. Протоколы Берг-коллегии. 1720 // Российский государственный архив древних актов. Ф. 271. Оп. 1. Д. 89.

27. Протоколы Берг-коллегии. 1721 // Российский государственный архив древних актов. Ф. 271. Оп. 1. Д. 90.

28. Разные решенные дела Комиссии об описи заводов и всякого имения умершего А. Демидова // Российский государственный архив древних актов. Ф. 271. Оп. 1. Кн. 587.

29. Раскин Н. М., Шафрановский И. И. Иоганн Фридрих Генкель // Ломоносов. Сборник статей и материалов. Т. 8. Л.: Наука, 1983. С. 76-87.

30. Распоряжения Акинфия Никитича Демидова. Январь-ноябрь 1742 // Российский государственный архив древних актов. Ф. 1267. Оп. 1. Д. 615.

31. Статейный список Андрея Виниуса. 1672-1674 // Российский государственный архив древних актов. Ф. 35. Оп. 1. Д. 16.

32. Сточик А. М., Затравкин С. Н. Медицинский факультет Московского университета в XVIII веке. М.: Шико, 2000. 464 c.

33. Фараджева С. А. Горное дело в Саксонии во второй половине XVI - начале XVII вв. (к проблеме генезиса капитализма в Германии). Автореф. дис. канд. ист. наук. М., 1979. 16 с.

34. Черкасова А. С. «...Чтоб железо делать, самым добрым мастерством». Из деловой переписки Акинфия Никитича Демидова // Демидовский временник. Кн. 1. Екатеринбург: Демидовский институт, 1994. С. 10-29.

35. Шевырев С. П. История Императорского Московского университета, написанная к столетнему его юбилею. 1755-1855. Репр. издание. М.: Издательство Московского университета, 1998. 600 с.

36. Юркин И. Н. Демидовы - ученые, инженеры, организаторы промышленного производства. Опыт науковедческой просопографии. М.: Наука, 2001. 333 с.

37. Юркин И. Н. Демидовы: Столетие побед. М.: Молодая гвардия, 2012. 447 с.

38. Bacmeister J. Essai sur la Bibliothèque et le Cabinet de curiosités et d'histoire naturelle de l'Académie des sciences de Saint Pétersbourg. SPb., 1776. 254 p.

39. Herrmann W. Bergrat Henckel. Ein wegbereiter der Bergakademie. Berlin: Akademie Verlag, 1962. 218 S.

\section{References (transliterated):}

1. Andreev A. Yu. Lektsii po istorii Moskovskogo universiteta. 1755-1855. M.: Izdatel'stvo Moskovskogo universiteta, 2001. $240 \mathrm{~s}$.

2. Baks K. Bogatstva zemnykh nedr. M.: Progress, 1986. 384 s.

3. Bessudnova Z. A. Geologicheskie issledovaniya v Muzee estestvennoi istorii Moskovskogo universiteta. 1759-1930. M.: Nauka, 2006. $246 \mathrm{~s}$.

4. Vulisanova G. A. Tri yashchika demidovskikh knig (iz istorii biblioteki P. G. Demidova) // Al'manakh Mezhdunarodnogo Demidovskogo fonda. Vyp. 2. M.: Klassika, 2003. S. 77-86.

5. Genkel' I. F. Rukovodstvo k khemicheskomu rudosloviyu. SPb.: Tip. Sukhoput. kad. korpusa, 1775. 248 s.

6. Golovshchikov K. D. Rod dvoryan Demidovykh. Yaroslavl': Tipografiya Gubernskogo pravleniya, 1881. 105 s. 


\section{Исторический журнал: научные исследования № 1 (25) • 2015}

DOI: $10.7256 / 2222-1972.2015 .1 .15676$

7. Dannaya A. N. Demidova na dom na Vasil'evskom ostrove, kuplennyi u gr. P. M. Apraksina // Rossiiskii gosudarstvennyi arkhiv drevnikh aktov. F. 1267. Op. 1. D. 765.

8. Demidova N. G. Rod Demidovykh: proshloe i nastoyashchee // Al'manakh Mezhdunarodnogo Demidovskogo fonda. M., 2001. S. 7-43.

9. Dokumenty i materialy po istorii Moskovskogo universiteta vtoroi poloviny XVIII veka / Podg. k pech. N. A. Penchko. T. 1: 17561764. M.: Izdatel'stvo Moskovskogo universiteta, 1960. $416 \mathrm{~s}$.

10. Dokumenty i materialy po istorii Moskovskogo universiteta vtoroi poloviny XVIII veka / Podg. k pech. N. A. Penchko. T. 3: 17671786. M.: Izdatel'stvo Moskovskogo universiteta, 1963. $518 \mathrm{s.}$

10a.Istoriya Moskovskogo universiteta (vtoraya polovina XVIII - nachalo XIX veka). Sbornik dokumentov. Tom 1: 1754-1755 / Otv. red. E. E. Rychalovskii. Sost., vstupit. stat'i i prim. D. N. Kostyshina. M.: Academia, 2006. $472 \mathrm{~s}$.

11. Istoriya roda Demidovykh // Rossiiskii gosudarstvennyi arkhiv drevnikh aktov. F. 1267. Op. 13. D. 22.

12. Krasnova E. I. Demidovskii kvartal «za Moikoi u Sinego Mostu» // Takie raznye Demidovy. SPb.: IPTs SPGUTD, 2007. S. 67-83.

13. Krasnova E. I. Demidovy. Rodoslovnaya rospis' // Takie raznye Demidovy. SPb.: IPTs SPGUTD, 2007. S. 120-142.

14. Krasnova E. I. 0 genealogii Demidovykh. Novye svedeniya // Takie raznye Demidovy. SPb.: IPTs SPGUTD, 2007. S. 39-42.

15. Malinovskii K. V. Sankt-Peterburg XVIII veka. SPb.: Kriga, 2008. 576 s.

16. Minuvshego fevralya 17 dnya... // Sankt-Peterburgskie vedomosti. 1755. № 21.14 marta.

17. Mikhail Vasil'evich Lomonosov. Perepiska. 1737-1765. M.: Lomonosov, 2010.512 s.

18. Morozov A. A. Lomonosov: Put' k zrelosti. 1711-1741. M.; L.: Izdatel'stvo AN SSSR, 1962. 488 s.

19. Muzei gornozavodskogo dela. Nizhnii Tagil. Ekaterinburg: Basko, 1995. $176 \mathrm{s.}$

20. Nikolaeva M. V. Sankt-Peterburg Petra I. Istoriya dvorovladenii: zastroika i zastroishchiki. M.: Progress-Traditsiya, $2014.1000 \mathrm{~s}$.

21. Nikolaeva M. V. Chastnye zastroishchiki petrovskogo vremeni - doma-dvortsy na naberezhnykh Bol'shoi i Maloi Nevy // Petrovskoe vremya v litsakh - 2008. SPb., 2008. S. 187-207.

22. Ob imeniyakh i zavodakh naslednikov Nikity i Akinfiya Demidovykh. 1702-1786 // Rossiiskii gosudarstvennyi arkhiv drevnikh aktov. F. 11. Op. 1. D. 95. Ch. 2.

23. Ocherki istorii kul'tury i byta starogo Nev'yanska. Lyudi, pamyatniki, dokumenty / Pod red. V. I. Baidina. Ekaterinburg: Izdatel'stvo Ural'skogo universiteta, 2001. $248 \mathrm{~s}$.

24. Petrov A. N. Savva Chevakinskii. L.: Lenizdat, 1983. $158 \mathrm{~s}$.

25. Pirogova E. P. Biblioteki Demidovykh: knigi i sud'by. Ekaterinburg: Sokrat, 2000. $208 \mathrm{~s}$.

26. Protokoly Berg-kollegii. 1720 // Rossiiskii gosudarstvennyi arkhiv drevnikh aktov. F. 271. Op. 1. D. 89.

27. Protokoly Berg-kollegii. 1721 // Rossiiskii gosudarstvennyi arkhiv drevnikh aktov. F. 271. Op. 1. D. 90.

28. Raznye reshennye dela Komissii ob opisi zavodov i vsyakogo imeniya umershego A. Demidova // Rossiiskii gosudarstvennyi arkhiv drevnikh aktov. F. 271. Op. 1. Kn. 587.

29. Raskin N. M., Shafranovskii I. I. Iogann Fridrikh Genkel' // Lomonosov. Sbornik statei i materialov. T. 8. L.: Nauka, 1983. S. 76-87.

30. Rasporyazheniya Akinfiya Nikiticha Demidova. Yanvar'-noyabr' 1742 // Rossiiskii gosudarstvennyi arkhiv drevnikh aktov. F. 1267. Op. 1. D. 615.

31. Stateinyi spisok Andreya Viniusa. 1672-1674 // Rossiiskii gosudarstvennyi arkhiv drevnikh aktov. F. 35. Op. 1. D. 16.

32. Stochik A. M., Zatravkin S. N. Meditsinskii fakul'tet Moskovskogo universiteta v XVIII veke. M.: Shiko, 2000. $464 \mathrm{~s}$.

33. Faradzheva S. A. Gornoe delo v Saksonii vo vtoroi polovine XVI - nachale XVII vv. (k probleme genezisa kapitalizma v Germanii). Avtoref. dis. kand. ist. nauk. M., 1979. 16 s.

34. Cherkasova A. S. «...Chtob zhelezo delat', samym dobrym masterstvom». Iz delovoi perepiski Akinfiya Nikiticha Demidova // Demidovskii vremennik. Kn. 1. Ekaterinburg: Demidovskii institut, 1994. S. 10-29.

35. Shevyrev S. P. Istoriya Imperatorskogo Moskovskogo universiteta, napisannaya k stoletnemu ego yubileyu. 1755-1855. Repr. izdanie. M.: Izdatel'stvo Moskovskogo universiteta, 1998. $600 \mathrm{~s}$.

36. Yurkin I. N. Demidovy - uchenye, inzhenery, organizatory promyshlennogo proizvodstva. Opyt naukovedcheskoi prosopografii. M.: Nauka, 2001.333 s.

37. Yurkin I. N. Demidovy: Stoletie pobed. M.: Molodaya gvardiya, 2012. 447 s.

38. Bacmeister J. Essai sur la Bibliothèque et le Cabinet de curiosités et d'histoire naturelle de l'Académie des sciences de Saint Pétersbourg. SPb., 1776. 254 r.

39. Herrmann W. Bergrat Henckel. Ein wegbereiter der Bergakademie. Berlin: Akademie Verlag, 1962. 218 S. 